\title{
The Tradition for Spiritual Learning (Tariqat) through a Sequence of Holy Phrases (Tijaniyah): The Case of Darussalam Boarding School
}

\author{
Aceng Kosasih ${ }^{1}$ \\ ${ }^{1}$ Program of Study in Islamic Religious Education, Department of General Education (DPU), Faculty of Social \\ Sciences Education (FPIPS), Universitas Pendidikan Indonesia (UPI), Indonesia \\ Correspondece: Aceng Kosasih, Faculty of Social Sciences Education, Universitas Pendidikan Indonesia, Jalan. \\ Dr. Setiabudhi No.229 Bandung, Indonesia. E-mail: cengsih15@gmail.com \\ Received: February 18, 2015 Accepted: April 13, 2015 Online Published: July 6, 2015 \\ doi:10.5539/ass.v11n21p71 URL: http://dx.doi.org/10.5539/ass.v11n21p71

\begin{abstract}
Indonesia has several courses for tasawwuf. These courses focus on the teaching of the inwardness of Islam. Each course has its own specifications. Against this background, the present study describes some of the tasawwuf courses in Indonesia which are considered to promote spiritual learning through the teaching of holy phrases (Tariqat-Tijaniyah), and it is these courses that are provided by most Islamic boarding schools in Indonesia, including the Darussalam Boarding School in Brebes. The study focuses on the social situation at this boarding school, especially the male section of Tijaniyah in Brebes. The study employs a qualitative approach with the help of an analytical method. Different types of dzikir and their contents are described, and the duties of male scholars as part of the Tijaniyah community are explored.
\end{abstract}

Keywords: tradition, thariqat tijaniyah, darussalam boarding school

\section{Introduction}

Tasawwuf is a dimension of Islam that developed around the second century of Hijriyah. Its development was a reaction to the luxurious life style of the elites from the Ummayyad and Abbasid dynasties. Its followers alienated themselves and focused on worshiping Allah and prioritizing soul purity. Since, its emergence, Sufism has become an interesting phenomenon (Al-Haramain, 2011). This Sufi as the first civilized intellectuals in worschipping God and developed advanced architect (Yassin \& NangkulaUtaberta, 2012) first existed in Kufah and Bashrah. Sufyan Ats-Sauri, Abu Hasyim and Jabir ibn Hayyan were popular Sufi figures in Kufah. Meanwhile, a more extreme tasawwuf developed in Bashrah with Hasan Al-Bashri and Rabiah Al-Adawiyah as its figures.

The core of the tasawwuf principle is worshiping God, removing oneself from mortal steadiness and comfort and alienating oneself from human civilization like the forefathers did (Istabad, 1988). According to Khanam (2006) Tasawwuf is one constituent of present-day sufism which may appeal to the modern mind. Followers believe that this was Prophet Muhammad (s.a.w.)'s way of life. Before becoming a prophet, he used to contemplate in the Cave of Hira by means of dzikir and ritual service to approach Allah.

Formerly, tasawwuf was part of zuhud (Note 1) in Islam (Zani, 2011). It teaches Muslims to concern themselves with and focus on worshiping God. An increasing variety of tasawwuf courses have been developed with the passage of time from the Muhammad era. Tasawwuf separated from zuhud because of its specified meaning and specific ritual activities.

In Indonesia, there are a variety of tasawwuf courses. Each course has been developed in a certain area. One course is Tariqat Tijaniyah, which was developed at the Darussalam Boarding School in Brebes. Like other tasawwuf courses, Tariqat Tijaniyah focuses its activities on approaching Allah by means of dzikir. Dzikir is a significant effort for someone to get closer to Allah. A consistency of dzikir is essential to recalling Allah and avoiding sinful acts.

Darussalam Boarding School conducts Islamic mission activities to disseminate Tariqat Tijaniyah principles besides its routine activities as an Islamic education institution is providing community services. This paper describes the traditions and rules of Tariqat Tijaniyah and how they are applied in people's daily lives. These are based on the principles of teaching. According to Asyafah (2014) the underlying problem facing the teaching of Islamic education across Indonesia is the inadequacy and ineffective teaching and learning methods. However, 
since teaching depends on the method of teaching and learning theory and or practice, the syllabus should be developed (Asyafah, 2014b), this is the reason for the discussion of Tasawwuf in Indonesia.

\section{Literature Review}

The teachings of Islam are known to have a very broad scope (al-Haramain, 2011). The term "tasawwuf" has several contradicting definitions. Through an examination of Al-Kalabadzi's (1993) writing on Tasawwuf, it has been found that experts have different understandings about the origin and definition of this word. The first understanding is that tasawwuf comes from "shuf", meaning rough wool because Sufi used to wear rough wool. This outfit was the symbol of modesty and moderate wellbeing. The second understanding is that tasawwuf is taken from "shafa" meaning "pure". This reflects the Sufi's habit that they keep themselves from sins and evil. The exact Sufi principle is to purify the soul by means of exercise or riyadhah. The third understanding is that tasawwuf is taken from the terminology associated with Ahl al-Suffah, who live in rooms around the Nabawiyah mosque in Madinah. They are poor people who have given their property and lives to follow Muhammad's pilgrimage from Mecca to Madinah. They sleep on stones with a suffah (horse saddle) as their pillow. Without spiritual power, it is impossible for them to sacrifice everything they have to receive Allah's love and follow their prophet's pilgrimage. The fourth understanding is that tasawwuf is derived from the word "shopos", which is a Greek word meaning "hikmah". Hikmah is benefit. Sufi have beneficial relations with benefits and wisdom because their souls tend toward benefit and wisdom. The fifth understanding is that tasawwuf is derived from the word "shaf". This word relates to people who are first in line to perform good deeds. From these definitions, tasawwuf can be explained as a mental state that consistently maintains soul purity and modesty, gives everything to charity and in the interest of good deeds, and maintains wisdom and dignity. This mental state is a reflection of the Sufi principle.

There are three different points of view on the terminology tasawwuf. The first point of view is that human beings are a limited source, meaning that people are dependent creatures. The second point of view is that human beings are creatures who live to survive; and the third view is that human beings are creatures who have God to worship.

According to the point of view that human beings are a limited source, tasawwuf can be defined as an effort to purify the soul and to avoid mortal life by focusing on worshiping Allah. Meanwhile, according to the second view, human beings must beautify themselves with good behavior taking their principles from the Quran and Hadith. The third point of view promotes the necessity of being conscious of the originality of the human soul in performing ritual activities related to God (Nata, 2003, p. 180).

If we combine the above three definitions of tasawwuf, it can be concluded that tasawwuf is an exercise of the soul by means of activities that free the soul from the effects of the mortal world, finally allowing Muslims to exhibit good behavior based on the Quran and Hadith. In other words, tasawwuf is an activity that is related to spiritual exercise with the aim of always being close to Allah or God (Nata, 2003, p. 181). The terminological definition of Tassawuf aligns with the view of Nasution (1992, p. 58), who states that tasawwuf is a science that provides Muslims with methods of getting as close to Allah as possible. Allah allows Muslims to become the flows of rivers that bring divine knowledge from God. Al-Ghazali frankly says that tasawwuf is a fardhu ain (Note 2) for every male and female Muslim who has mukallap status (Note 3). There is no Muslim who is free from sins and spiritual sickness; only prophets are free from sins and spiritual sickness because Allah has guaranteed their souls are immune from evils and purified of sins.

According to Al-Ghazali, there are two kinds of nafs (passion); first, nafs means anger and sexual desire of the human being, which leads to the term that is commonly used by Sufi to define every bad deed conducted by a human being as bad behavior. Therefore, Sufi usually say: "People must defeat their ego and destroy it". As Muhammad's Hadith says, "The worst enemy is the ego between the two sides of your body (where the two sides are the thighs). Secondly, the word nafs means the soul or the core of the human being himself and his personality. Nafs can also be categorized in several different categories according to the situation. A soul that is calm and can be controlled and is clean from every bad desire - is called al-nafs al-muthmainnah (calm soul). The first definition of nafs does not consider the final return of mankind to God after death; this kind of nafs comes from Satan.

Meanwhile, there is nafs that has not reached the calmness level, but encourages its owner to defeat a bad desire and to destroy it. This kind of nafs is called al-nafs al-lawwamah (the soul that always criticizes its owner). It criticizes the owner who is lazy in fulfilling his duty to worship God. If a soul stops the critic and fully follows a bad desire, it is called al-nafs al-amarah bi al-su'i (the soul that leads to a bad deed). This kind of nafs belongs to the first category in the same definition. According to these considerations, a soul purification exercise should be 
performed in the manner of tasawwuf. Imam al-Junaid al-Baghdadi as quoted by Kabbani (2007: 86) defines Sufi as people who wear wool and stand at the peak of soul purity, according to Muhammad's life principle stated in Hadith. A sufi endures bodily suffering and leaves behind any mortal happiness and wellbeing. Tasawwuf in Islam developed around the second century of Hijriyah. There are two types of factors that affect tasawwuf.

\subsection{External Factors}

There are several external factors that affect tasawwuf.

- Tasawwuf is based on the Christian way of life. Priests and nuns must alienate themselves in a church or dormitory. They must set themselves apart from human civilization. This is clearly seen in the Sufi's behavior in terms of the zuhud principle.

- Tasawwuf is based on the philosophy of Pythagoras that states that human souls are immortal and live in the world as strangers. The body or physical presence is only a prison for the soul. To attain real happiness in heaven, a person needs to purify his soul by leaving behind his material life and by contemplating. The Pythagoras philosophy is assumed to have triggered the zuhud way of life in tasawwuf.

- Tasawwuf in Islam is based on the emanation of Plotinus, explaining that manifestation comes from the sublime substance of God. The soul comes from God and will return to Him in the end. That the soul enters the material body makes it filthy, and thus, once it returns to God, it needs to be purified. Approaching God as closely as possible by contemplating and leaving the material world is a way of purifying the soul from the effects of the filthy body.

\subsection{Internal Factors}

There are also internal views in Islam that affect tasawwuf. These factors are recitation of the Quran and Hadith; in the Quran, for example, there are several verses describing how mankind is very close to Allah. An example is as follows. And when My servants ask thee about Me, say: 'I am near. I answer the prayer of the supplicant when he prays to Me. So they should hearken to Me and believe in Me, that they may follow the right way.' (Quran, al-Baqarah, verse: 186)

The conclusion from this verse is that Allah is very near to mankind. He will listen and realize every pray presented to Him, but indeed with several conditions. The description about God's intimation to mankind is also recited in the following verse. And assuredly, We have created man and We know what his physical self-whispers to him, and We are nearer to him than even his jugular vein. (al-Quran, Qaf: 16)

Another trigger of tasawwuf in Islam is that Islam has three dimensions, namely Iman or faith, Islam and Ihsan. The Iman dimension consists of faith or belief in Allah, belief in His angels, His holy books, His messengers, belief in the of judgement and finally belief in His fate (Allah's predestination of mankind). The last belief generates Kalam or Islamic theology. The Islam dimension consists of syahadat (a Muslim's confession of his belief in God), shalat (praying five times per day), zakat (charity tax), and going to hajj. This dimension leads to Fiqih science. Meanwhile, the Ihsan dimension clearly generates tasawwuf because tasawwuf is the implementation of this dimension. Ihsan demands a Muslim to be always at the peak of the Iman's dimension and to realize all his responsibilities and to perform good deeds. Thus, tasawwuf is actually affected by internal factors, namely the Hadith and Quran, even without the external factors. The term tasawwuf was not used in the Muhammad era.

Tariqat is derived from the Arabic word tariqah, and the plural from is tara'iq, meaning way, method, course or state. The term tariqat is commonly used by tasawwuf experts to describe the ways chosen by Sufi to approach God. Thariqat for Sufi means a system used to exercise the soul and to purify oneself from evil characteristics and to replace them with good behaviors through dzikir and spiritually internalizing God. One method is to be ever conscious of evil and good behaviors and to continue to recall Allah by means of dzikir to avoid anything but Allah. The following are the benefits of following tariqat stated by Aziz (2009:1).

\subsubsection{Consistency}

People who do not follow the tariqat method will find it difficult to maintain consistency in recalling Allah by means of dzikir. Meanwhile, those who follow tariqat, and particular those who are expert, will continue to uphold their responsibilities as Muslims in any situations. Thus, they will gain twice the merit from Allah because of their consistency in serving Him.

\subsubsection{The Forgiving of Sins}

Every human being has sin, and there is the proverb saying that to err is human. The tariqat principle teaches the follower to perform good deeds as much as possible to replace sins. All routine activities of Thariqat Tijaniyah, 
such as istighfar (Note 4) and shalawat (Note 5) relate to the performing of good deeds that can replace and minimize human sins.

\section{Methodology}

The present study employs an analytical descriptive method and grounded research. Grounded research is a scientific research method commonly used to comprehensively comprehend or determine activities carried out by research objects in the field. As mentioned by Basri (2004, p. 10), grounded research is oriented toward formulating theory that is to be further used to research the individual, group or community. This research differs from other approaches. It has no hypothesis or rigid theoretical framework. Sugiono (2008, p. 96) stated that there is no need for a hypothesis at the beginning of such descriptive research.

The purpose of the grounded research model is to develop substantive or even general theory. The data obtained can thus advance theory. Qualitative research, especially grounded research, builds a concept or preposition without initial preconceptions (Basri, 2004, p. 10). In the present study, the grounded research approach is used to evaluate kinds of dzikir practiced at the Darussalam Boarding School in Brebes and to determine how the male scholars internalize dzikir values.

The present research was conducted at the Darussalam Boarding School, Jati Barang, Brebes in Central Java. The qualitative research does not use the term "population". Instead, the "social situation", as used by Spradley and quoted by Sugiono (2008, p. 297), consisting of a place, actor and activity that interact in synergy, will be used. The social situation at the boarding school includes male scholars and their activities. These are later considered objects of research.

\section{Results}

As previously mentioned, the term tariqat is derived from the Arabic word tariqah, and the plural from is tara'iq, meaning way, method, course or state. The term tariqat is commonly used by the tasawwuf expert to describe the ways chosen by Sufi to approach God. Thariqat for Sufi means a system used to exercise the soul and to purify oneself from evil characteristics and to replace them with good behaviors with dzikir and the spiritually internalization of God. One method is to be ever conscious of evil and good behaviors and to continue to recall Allah by means of dzikir to avoid anything but Allah (Nata, 2003, p. 270).

The purposes of implementing Thariqat Tijaniyah are (a) getting closer to Allah, (b) the possibility of compunction, (c) to be consistent in dzikir, and (d) to live happily in the world and thereafter. Thariqat is a method used by the male scholars to get near to Allah as much as possible. The closer they are, the more they dzikir or recall Allah. This means they will be protected from any material business that may take them far from God. and turn into their destiny. The main aim of this thariqat is to be consistent in dzikir or to be in a state of remembering Allah. The talqin or expert in tariqat (1) maintains dzikir and (2) does not break Allah's commands and rules. Tariqat also provides male scholars with compunction, by reminding them that every human being must have sins. Therefore, they must always be in the right way to beg forgiveness by means of dzikir through continual praying every morning and evening.

When a scholar repeats istighfar or begs forgiveness from Allah, it means he is in a conscious state that allows him to perform dzikir consistently and leads him to the level of mahabbah or loving his God. The first indicator that he loves his God is that he always remembers Him; second, he often calls His name over and over; third, he always wants to meet Him. The highest level of this love is that there will be no other but Him in his mind and life. Whenever this happens, true happiness in life and thereafter is achieved.

This study focuses on Tariqat-Tijaniyah at the Darussalam Boarding School. The main activity of tariqat is dzikir. In this tariqat, dzikir is divided into three categories: dzikir bil jinan, dzikir bil lisan and dzikir by action.

\subsection{Dzikir Bil Jinan (Praising by Heart)}

Dzikir by heart is commonly called dzikir khafi. It is spoken in the heart or without spoken words. This dzikir only fulfills somebody with a consciousness of God's existence. They can feel Him as their heart beats. In other words, a person's heart that is not fulfilled with dzikir is a dead heart because there is no spiritual communication with The Sublime Life or God in their heart. In the Quran, the sublime Life is described with sky light and earth. When there is no connection with the source of light, the heart will not receive light and dies. To achieve this dzikir, a continual discipline exercise and guidance from a teacher called a muqaddam is necessary.

The basic foundation of this dzikir is the Quran verse Adapun yang dijadikan landasan berdzikir dengan hati adalah firman Allah yang berbunyi, which translates as "And remember thy Lord in thy mind with humility and 
fear, and without loudness of speech, in the mornings and evenings; and be not of the neglectful". (QS. Al-A'raf: 205).

According to a hadith of the Prophet (p.b.u.h) from Abu Hurayrah, the Prophet said:

There is also Hadith from Muhammad narrated by Abu Hurairah stating that the Prophet said that Allah always acts as His humankind assumes or wishes even if the wish is only whispered in their heart. Allah will also always remember those who remember Him in front of other creatures and elevates their position among them all.

\subsection{Dzikir by Saying the Words Loud}

Dzikir is performed with spoken words by uttering the words of a certain dzikir with a thayyibat (Note 6) sentence using both a loud voice and a soft voice that can only be heard by the speaker. The spoken dzikir implemented by the male scholars at the boarding school consists of the following.

- Wirid lazimah. This dzikir is written twice per day, once in the morning and once in the afternoon, personally or munfarid. The words of this dzikir must not be spoken.

- Wirid Wadzifah is written once per day.

- Wirid Hailallah is written once per week.

There are eight rules that should be obeyed in writing the spoken dzikir. (1) The words of dzikir must normally be able to be heard by the reader of the words. (2) The ikhwan or male scholar must be pure from all filth that may be attached to the body, clothes, possessions, or location. (3) He must be chaste from all hadats, both little hadats (urination) and big hadats (defecation). (4) He should cover his genitalia perfectly. (5) He is not allowed to talk. (6) He must face qibla (west) or Kabah. (7) He must sit. (8) The wadzifah and hailalah should be conducted collectively if there is a Tijani scholar. The lazimah must be conducted twice per day.

- The first time is after ashar prayer (afternoon prayer), but if there is obstacle when the time of shubuh or dawn comes and later it continues to the time after the dawn, and he cannot practice the dzikir yet, he must make it up in the next dzikir.

- The second time is after shubuh prayer (dawn prayer) until the time of dhuha (a prayer that is not compulsory or sunnah done before afternoon during working hours). If there is an obstacle that prevents him from fulfilling the requirement lasting until maghrib pray (a prayer that is made when the sun is fading), it is better to conduct this lazimah earlier during taqdim, which proceeds shubuh prayer. However, if the requirement has not been fulfilled by the time of maghrib prayer, the dzikir must be made up. If he cannot finish the dzikir by the shubuh time, he must continue it after shubuh. The duration of taqdim practice before shubuh is around 90 minutes after isya prayer.

The lazimah practice sequence at the boarding school is described in greater detail below.

First, the intention to practice lazimah both in the morning and afternoon is stated. The wording of the intention is given below.

$$
\begin{aligned}
& \text { نويت التعبد تقربا الى اللة باداء وردنا اللازم في طريقتنا التجا نية }
\end{aligned}
$$

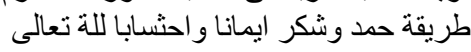

The istighfar is written 100 times; the shigat or wording is written here.

These words function to clean the soul from bad deeds. The basic purpose of attending this tariqat is taqarrub or approching God. Therefore, the scholar must previously beg forgiveness using istighfar words to clean away sins and to become pure. Briefly, istighfar is a process of cleaning spiritual dirt and replacing it with saintly values. This is based on His commandment in Quran, Surah An-Nisa: "And whoever does a wrong or wrongs himself but then seeks forgiveness of Allah will find Allah Forgiving and Merciful”. (QS. An-Nisa: 110).

In a Hadith narrated by Anas, Muhammad referred to Allah's forgiveness of great sins and how Merciful He is.

Allah promises that every prayer and wish will be responded to. Whenever humankind begs for forgiveness even if for the great sins as high as the sky but they keep begging for it by means of istighfar, He will forgive them. If those human beings also come to Allah with great mistakes as big as the earth with one condition that they never associate Allah to anyone and anything, Allah forgive such mistakes, however, big they may be (trans: Hadith narrated by Turmudhi)

Next, the shalawat or praise to Muhammad is read 100 times using any text of shalawatt, such as the following.

$$
\text { اللهم صل علي سيدنا محمد و على اله }
$$


Note that it is much better to read the faith shalawat first before reading the above shalawat 100 times. The words of the faith shalawat are as follows.

$$
\begin{aligned}
& \text { اللهم صل على سيدنا محمد نا لفاتح لما اغلق و الخا تم لما سبق ناصر الحق با لحق و الهادي } \\
& \text { الى صر اطلك المستقيم و على اله حق قدره ومقداره الهار العظيم }
\end{aligned}
$$

Reading shalawat in this way or repeating the dzikir functions to bring man closer to the Creator (to get God's mercy) and mediatory to make istighfar prayers accepted by Allah. ............. and therefore to ask forgiveness, pray for Muhammad (S.A.W). This conviction is based on Muhammad's companion or apostle Umar bin Kahttab who mentions that: A servant's prayer will be delayed from sky to earth until shalawat is uttered and presented to Muhammad. (QS. An-Nisa: 110)

\subsection{Dzikir with Action}

The dzikir with action practiced at Darussalam Boarding School consists of rituals and social implementations. The ritual worship includes Five Pillars consisting of salah and fasting. It is better to practice salah collectivity; even those male tariqat scholars who stay at the school receive punishment if they do not practice prayer in a congregation. Meanwhile, dzikir implementation in social life is related to daily-life activities such as occupational activities. For example, traders implement dzikir at the principle of trading or business, and workers implement dzikir when at work. Thus, a male Tijani scholar is assumed to have completed the social dzikir if the rules of the daily professional activities are not broken. There are conditions for being part of Tijaniyah.

\subsubsection{Preparedness Level of a Male Scholar Required to Be Talqin (Training or Education) Tariqat-Tijaniyah}

There are five preconditions that need to be fulfilled. (a) A person must be a member of Tariqat-Tijaniyah and intend to feel compunction. (b) They must not be enrolled in any tariqat community. If they are, they must leave the tariqat group. In other words, the tariqat membership cannot be affiliated with other memberships. (c) They have to obey and maintain Muhammad's regulations and principles, namely Sunnah. (d) Membership is for their entire life. (e) They must not visit any religious leader but the tariqat group leader both in life and afterward (Fathullah, 2007:191). If a person can fulfill these five conditions, they can enroll to be members of the tariqat. Next, the teacher will educate and train them.

\subsubsection{Tariqat-Tijaniyah Talqin (Education)}

Talqin is a procession that includes teaching and guidance given by the teacher to male scholars to implement Tijaniyah principles. A student must state his loyalty and allow him-self to be guided and trained to receive Allah's mercy and affection.

\subsubsection{Responsibilities of the Tijaniyah Male Scholars}

A male scholar is trained so that all tariqat responsibilities may be applied to him. He must consistently practice all dzikir without excuse. The dzikir mainly consist of the following.

- Wirid lazimah- which is practiced twice per day, once in the morning and once in the afternoon.

- Wirid Wadzifah- which is practiced once per day at any time.

- Wirid Hailallah- which is practiced once per week in the afternoon after ashar prayer by maghrib prayer and around Friday prayer.

\subsubsection{Tarbiyah or Education}

Tarbiyah is a guidance or training activity that internalizes dzikir values. This activity relates to Quran recitation conducted only for male scholars every Monday morning. Generally, there will be other activities inserted in this main activity, such as hailallah wirid, khotmi, Syekh Ahmad al-Tijani's memorial or a great memorial event.

The main purpose of this tarbiyah is to guide and motivate scholars in dzikir to Allah. Therefore, all the thariqat rules and principles must be upheld so that the students will continue on the path to receive Allah's mercy and affection.

\section{Conclusion}

There are three types of dzikir practiced in the tariqat, namely dzikir bil jinan, dzikir bil lisan and dzikir with action. However, the male scholars or muslims are mainly required to practice spoken dzikir by means of wirid (dzikir repeated a certain number of times). The wirids are lazimah, wadzifah and hailallah. There are no absolute rules in implementing dzikir with heart and action. These two forms of dzikir are usually practiced by common Muslims in general. Dzikir practices of Tariqat-Tijaniyah include istighfar, shalawat and tahlil sentences included in lazimah, wadzifah and hailallah has a strong religious base in the Quran and Hadith. 
The method of dzikir practiced by the tariqat has several phases: (1) preparation of a male scholar to be educated or talqin in the tariqat, (2) training according to the Tariqat-Tijaniyah principle, (3) fulfilling the responsibilities of the Ikhwan Tijani or Tijaniyah scholar, (4) education and (5) performance of the traditions and activities of the tariqat. The traditions include a) the tradition of the ritual Dzikir Wajibah, b) Tradition: Ijtima" Hailallah", c) the tradition of Dzikir Ikhtiyari, d) the tradition of Manaqiban, e) Tradition Haul Akbar, f) Idul Khotmi, and g) the tradition of Syekh Ahmad al-Tijani memorial. These traditions promote consistent in dzikir and finally, the internalization of the required values.

\section{References}

Al-Haramain, E. (2011). Shifting Orientation in Sufism: Its Development and Doctrine in History, Indonesian Journal of Islam and Muslim Societies, 1(2), 273-296.

Al-Kalabadzi. (1993). Al Ta'arruf li madzhab ahl al-tasawwuf. Beirut: Dar al-Kutub al-Ilmiyyah

Al-Qur'an dan terjemahannya. (2006). Departemen Agama Republik Indonesia. Pustaka Agung Harapan.

Asyafah, A. (2014a). The Method of Tadabur Qur'an: What Are the Student Views? International Education Studies, 7(6), 98-105.

Asyafah A. (2014b). Research based instruction in the teaching of islamic education. Springerplus, 3, 755, Published online 2014 Dec 19. http://dx.doi.org/10.1186/2193-1801-3-755.

Aziz, A. (2009). Istiqamah, Kunci sukses Dunia Akhirat. Surabaya. Alfalah.

Basri, H. (2004). Minuman Cinta Menyelami Esensi Ajaran Tasawuf. Jakarta: Paramarta.

Fathullah, A., \& Adhiman, F. (2007). Thariqat Tijaniyah Mengemban Amanat Rahmatan lil Alamin. Kalimantan Selatan: Yayasan Al-Anshari.

HR. Bukhari, Muslim, Tirmizi, Nasai dan Ibnu Majah.

Istrabad, Z. S. (1988). "The Principles of Sufism" (Qawa'id al-Tasawwuf"): An annotated Translation with Introduction. Indiana University.

Khanam, F. (2006). Sufism an Introduction. India: Good Wordbooks.

Kabbani, S. M. H. (2007). Tasawuf dan Ihsan. Jakarta: Serambi Ilmu Semesta.

Nasution, S. (1992). Metode Research. Jakarta: Bumi Aksara.

Nata, A. (2003). Akhlak Tasawuf. Jakarta. Raja Grafindo Persada.

Sugiyono. (2008). Metode Penelitian Pendidikan. Bandung. Alfabeta.

Yassin, A. A., \& Utaberta, N. (2012). Architecture in the Islamic Civilization: Muslim Building or Islamic. Architecture. Journal of Islamic Architecture, 2(2), 52-100.

Zani, a. a. (2011). The attitude of zuhud according to hamka in tafsīr al-azhār. Thesis Submitted to Faculty of Uşhūluddīn to fulfill a requirement for undergraduate degree in Islamic Theology (Tafsīr Ĥadīśt). Semarang:

State Institute of Islamic Studies Semarang.

\section{Notes}

Note 1. Zuhud is one of the Islamic ways of life that reflects modesty and moderate material steadiness or generosity.

Note 2. Personal duty that must be performed by every Muslim but can be performed by other Muslims having a family relation.

Note 3. The category of Muslim who is biologically mature and mentally healthy.

Note 4. A kind of prayer with wording that especially begs forgiveness from Him.

Note 5. Prayer especially refering to oneself as a follower of Muhammad to get his help thereafter.

Note 6 . The value and judgment of goodness and benefits based on Islam principles.

\section{Copyrights}

Copyright for this article is retained by the author(s), with first publication rights granted to the journal.

This is an open-access article distributed under the terms and conditions of the Creative Commons Attribution license (http://creativecommons.org/licenses/by/3.0/). 